Abstracta Iranica

Revue bibliographique pour le domaine irano-aryen

Volume 40-41 | 2019

Comptes rendus des publications de 2017-2018

\title{
Gilles Courtieu. «L'arc des arsacides en dépit du bon sens »
}

\section{Leonardo Gregoratti}

\section{(2) OpenEdition \\ 1 Journals}

\section{Electronic version}

URL: http://journals.openedition.org/abstractairanica/49692

DOI: 10.4000/abstractairanica.49692

ISBN: 1961-960X

ISSN: 1961-960X

Publisher:

CNRS (UMR 7528 Mondes iraniens et indiens), Éditions de l'IFRI

Electronic reference

Leonardo Gregoratti, "Gilles Courtieu. "L'arc des arsacides en dépit du bon sens »", Abstracta Iranica [Online], Volume 40-41 | 2019, document 34, Online since 30 October 2019, connection on 17 April 2021. URL: http://journals.openedition.org/abstractairanica/49692 ; DOI: https://doi.org/10.4000/ abstractairanica.49692

This text was automatically generated on 17 April 2021.

Tous droits réservés 


\title{
Gilles Courtieu. « L'arc des arsacides en dépit du bon sens »
}

\author{
Leonardo Gregoratti
}

\section{REFERENCES}

Gilles Courtieu. « L'arc des arsacides en dépit du bon sens », Studia Iranica, 46, 2017, 193-203

1 Courtieu in his short but extremely detailed paper focuses on a detail of Arsacid coinage that has always stood in front of scholars' eyes, but has never been analysed with the due attention: Arsaces' bow. That the weapon depicted is a compound bow has been already pointed out in the past. No scholar before though has noticed that most of the bows wielded in Parthian coins are asymmetrical. Courtieu thinks this fact is intentional and represents the effort of depicting accurately the Parthian bow that was used by horse riders. An asymmetrical bow was more suitable for large size horses, it rendered easier to move the weapon from one side of the horsehead to the other and it limited the risk of touching the horse flanks while shooting. Arsaces' gesture is taken into consideration as well. The legendary figure is not simply holding the bow. The composition and in particular the connection between the king's eyes and the bowstring suggest to the author that Arsaces is performing a common operation, well known to all archers, in particular to those using a compound bow: he is checking the weapon's condition verifying the tension of the string and the correct line up of the extremities. Arsaces is showed testing the functioning of the weapon that was the symbol of Parthian military power, an operation very familiar to each of his soldiers. 


\section{AUTHORS}

\section{LEONARDO GREGORATTI}

Durham University 